\title{
ANALISIS STILISTIKA DAN NILAI PENDIDIKAN KARAKTER DALAM LIRIK-LIRIK LAGU FOURTWNTY ALBUM LELAKU SERTA RELEVANSINYA SEBAGAI BAHAN AJAR BAHASA INDONESIA TINGKAT SMA
}

\author{
Arina Dicka Maretta, Elisabeth Nugraheni Eko Wardani, Atikah Anindyarini \\ Universitas Sebelas Maret \\ Surel: arinadickamaretta@gmail.com
}

\begin{abstract}
Abstrak: Penelitian inimerupakan penelitian kualitatif deskriptif menggunakan analisis stilistika untuk mendeskripsikan adanyagaya bahasa, pilihan kata, citraan, nilai-nilai pendidikan karakter, serta relevansi lirik-lirik lagu Fourtwnty album Lelakusebagai bahan ajar pembelajaran Bahasa Indonesia tingkat SMA. Teknik pengumpulan data menggunakan analisis isidan wawancara. Uji validitas data menggunakan teknik triangulasi metode dan teori. Penelitian ini menghasilkan adanya (1) gaya bahasadidominasi oleh sinpoke, repetisi epizeuksis, dan simbolik yang mampu menciptakan efek estetis, khas, serta penegasan;(2) pilihan kata didominasi oleh konotatif dan sapaan khas serta nama diri yang dapat menciptakan keindahan dan kekhasan; (3) citraan didominasioleh citra penglihatan yang mampu membangkitkan imaji pembaca; (4)nilai-nilai pendidikan karakter didominasi oleh nilai religius, kerja keras, komunikatif, dan cinta damai yang diharapkan dapat membentuk karakter pembaca; serta (5) Lirik-lirik lagu Fourtwnty album Lelakudapat digunakan dan dikembangkan sebagai bahan ajar pembelajaran Bahasa Indonesia kelas X khususnya materi apresiasi puisi pada kompetensi dasar 3.8 dan 4.8.
\end{abstract}

Kata Kunci : stilistika, puisi, bahan ajar, majas, diksi, citraan

\section{STILISTICS ANALYSIS AND CHARACTER EDUCATION VALUES IN LIRICS SONG FOURTWNTY IN ALBUM $L E L A K U$ AND ITS RELEVANCE AS LEARNING MATERIALS INDONESIAN LANGUAGE OF SENIOR HIGH SCHOOL LEVELS}

\begin{abstract}
This is descriptive qualitative research using stylistic analysis to describe the existence of language style, diction, image, educational values of the character, and the relevance of the lyrics of Fourtwnty album Lelaku as a teaching material for Indonesian language learning at high school. Data collection techniques use content analysis and interviews. Validity test of data using medhod triangulation techniques and theory. The results of this study indicate

(1) the language style dominated by sinpoke, repetition epizeuksis, and symbolic able to create aesthetic effects, typical, and affirmation; (2) diction is dominated by connotative and typical greetings and names that can create beauty and uniqueness; (3) the image is dominated by vision capable of generating the image of the reader; (4) the values of character education are dominated by religious values, communicative, hard work, and peaceful love that is expected to shape the character of the reader; and (5) The lyrics of Fourtwnty's album Lelaku can be used and developed as learning materials of class X Indonesian language especially poetry appreciation material on basic competence 3.8 and 4.8 .
\end{abstract}

Keywords : stylistic, poetry, teaching materials, majas, diction, image

\section{PENDAHULUAN}

Sastra merupakan sebuah karya seni yang bermedia atau berbahan utama bahasa, ada beberapa jenis karya sastra, diantaranya drama, prosa dan puisi. Lirik lagu juga merupakan salah satu jenis karya sastra berbentuk puisi yang paling dekat dengan kehidupan manusia yang disajikan dengan iringan musik. Lirik lagu dapat menjadi bagian dari karya sastra berbentuk puisi karena lirik lagu memiliki persamaan dengan puisi, yaitu sebuah media untuk 
mengungkapkan pikiran dan perasaan seseorang serta dalam puisi maupun lirik lagu, pemilihan kata sama-sama dilakukan secara cermat dalam hal rima, irama, maupun harmonisasinya (Erowati \& Mualim,2015: 171).

Sebagai karya sastra yang paling dekat dengan kehidupan manusia seharihari, lirik lagu haruslah menjadi karya sastra yang berkualitas dengan memenuhi fungsi dari karya sastra itu sendiri. Karya sastra memiliki fungsi dulce et utile yang memiliki arti indah dan berguna, karya sastra dapat memberikan rasa keindahan dan sekaligus kegunaan untuk para penikmatnya (Horace dalam Rokhmansyah, 2014:8). Dengan demikian, lirik lagu seharusnya bukan hanya mengandung nilai keindahan yang tinggi, melainkan juga mengandung nilai kebermanfaatan bagi para penikmatnya.Fourtwnty merupakan salah satuband Indonesia yang terbentuk pada tahun 2010 dan terkenal memiliki ciri yang khas serta adanya nilai-nilai moral dalam menyajikan lagu terutama pada lirik-lirik dalam lagunya, namun terkadang hal ini tidak dibarengi dengan kemampuan pendengar dalam memahami makna sebenarnya yang ada pada lirik lagu tersebut.

Berdasarkan latar belakang di atas, penelititelah melakukan penelitian mengenai keindahan dan makna pada liriklirik Lagu Fourtwnty melalui analisis stilistika serta kebergunaan lirik-lirik lagu Fourtwnty melalui analisis adanya nilainilai pendidikan karakterdan relevansinya sebagai bahan ajar Bahasa Indonesia. Penelitian ini bertujuan untuk mendeskripsikan: (1) gaya bahasa dalam lirik-lirik lagu Fourtwnty album Lelaku;

(2) diksi atau pilihan kata dalam lirik-lirik lagu Fourtwnty album Lelaku; (3) citraan dalam lirik-lirik lagu Fourtwnty album Lelaku; (4) nilai-nilai pendidikan karakter lirik-lirik lagu Fourtwnty album Lelaku; dan (5) relevansi lirik-lirik lagu Fourtwnty album Lelaku sebagai bahan ajar Bahasa Indonesia tingkat SMA.
Stilistika adalah bagian ilmu linguistik yang membahas gaya dalam konteks kesusastraan, khususnya gaya bahasa yang mempunyai fungsi artistik (Hartono, 2003: 4). Menurut Ratna (2008: 3), Stilistika (stylistic) merupakan ilmu tentang gaya, sedangkan stil (style) secara umum adalah cara-cara yang khas, bagaimana segala sesuatu diungkapkan dengan cara tertentu, sehingga tujuan yang dimaksudkandapat dicapai secara maksimal. Al-Ma'ruf (2009:10) secara jelas menyatakan bahwa stilistika merupakan ilmu yang mengkaji wujud pemakaian bahasa dalam karya sastra yang meliputi seluruh pemberdayaan potensi bahasa, keunikan dan kekhasan bahasa serta gaya bunyi, pilihan kata, kalimat, wacana, citraan, hingga bahasa figuratif. Melalui berbagai pendapat tersebut dapat diperoleh makna bahwa stilistika merupakan ilmu bidang linguistik terapan yang mengkaji mengenai kekhasan gaya bahasa yang digunakan pengarang dalam menciptakan sebuah karya sastra.

Membahas mengenai stilistika, Satoto (2012: 35) menjelaskan bahwa 'style', 'stail' atau 'gaya', yaitu cara yang khas dipergunakan oleh seseorang untuk mengutarakan atau mengungkapkan diri gaya pribadi. Cara pengungkapan tersebut bisa meliputi setiap aspek kebahasaan: diksi, penggunaan bahasa kias, bahasa pigura (figurative language), struktur kalimat, bentuk-bentuk wacana, dan sarana retorika yang lain.Agar ranah kajian tidak terlalu luas, kajian stilistika biasanya dibatasi pada suatu teks tertentu dengan memperhatikan prefensi penggunaan kata atau struktur bahasa, mengamati hubungan-hubungan pilihan itu untuk mengidentifikasi ciri-ciri stilistik seperti morfologi, leksikal, retoris atau deviasi (Sudjiman dalam Hakim,2010:18). Penelitian analisis lirik-lirik lagu Fourtwnty album Lelaku ini peneliti membatasi penelitian dengan menganalisis stilistika berupa diksi (pilihan kata), gaya bahasa, dan unsur pencitraan. 
Diksi adalah pemilihan kata yang tepat, padat dan kaya akan nuansa makna dan suasana yang diusahakan secermat dan seteliti mungkin, dengan mempertimbangkan arti sekecil-kecilnya baik makna denotatif, maupun makna konotatif sehingga mampu memengaruhi imajinasi pembacanya (Rokhmansyah, 2014: 16). Menurut pendapat Sutardi

(2012: 27) diksi merupakan pilihan kata dengan memilih, memilah, dan menentukan kata yang akan digunakan untuk mengungkapkan perasaan.

Sejalan dengan pendapat para ahli tersebut, Al-Ma'ruf (2009: 49) berpendapat bahwa diksi adalah pilihan kata-kata yang dilakukan pengarang dalam karyanya guna menciptakan efek makna tertentu. Jadi dapat disimpulkan bahwa diksi merupakan kreativitas pengarang dalam memilih dan memadukan kata-kata sehingga dapat menimbulkan makna tertentu dan mampu memengaruhi imajinasi pembaca. Beberapa jenis diksi pernah disampaikan oleh Al-ma'ruf (2009: 53) yaitu, (1) Kata Konotatif; (2) Kata Konkret; (3) Kata Sapaan Khas dan Nama Diri; (4) Kata Serapan; (5) Kata Vulgar; dan (6) Kata dengan Objek Realitas Alam.

Gaya bahasa merupakan cara mengungkapkan pikiran melalui bahasa secara khas yang memperlihatkan jiwa dan kepribadian penulis atau pemakai bahasa Keraf (2007: 113).Gaya bahasa sering disebut dengan istilah majas, Majas diterjemahkan dari kata trope (Yunani), figure of speech (Inggris), berarti persamaan atau kiasan (Ratna, 2013: 3). Ratna juga menjelaskan bahwa majas (figure of speech) adalah pilihan kata tertentu sesuai dengan maksud penulis atau pembicara dalam rangka memperoleh aspek keindahan. Nurgiyantoro (dalam Al Ma'ruf, 2009: 61) berpendapat bahwa permajasan merupakan teknik pengungkapan bahasa ataupun penggayabahasaan yang maknanya tidak menunjuk pada makna harafiah kata-kata yang mendukungnya, tetapi pada makna yang tersirat.
Melalui berbagai pendapat tersebut, dapat disimpulkan bahwa majas merupakan penggunaan bahasa yang memiliki makna tersirat atau makna yang tersembunyi dari apa yang diungkapkan serta bertujuan mendapatkan aspek keindahan.Pada umumnya majas dibedakan menjadi empat macam, yaitu : majas penegasan, perbandingan, pertentangan, dan majas sindiran. Beberapa jenis majas tersebut dibedakan lagi menjadi subjenis lain sesuai dengan cirinya masing-masing.

Citra merupakan reproduksi mental, suatu ingatan masa lalu yang bersifat indrawi dan berdasarkan presepsi-dan tidak selalu bersifat visual (Wellek dan Warren dalam Sutejo,2010: 19). Menurut Pradopo (dalam Sutejo,2010:19) citra merupakan gambar-gambar dalam pikiran dan bahasa yang meng-gambarkannya. Menurut pendapat Sayuti (dalam Al-Ma'ruf, 2009: 76) citraan merupakan serangkaian kata yang mampu membentuk gambaran mental atau membangkitkan pengalaman tertentu. Menurut Scott (dalam Al-Ma'ruf, 2009: 76) citraan merupakan penggambaran angan-angan dalam kata untuk mendeskripsikan sesuatu sehingga pembaca dapat melihat, merasakan, dan mendengarnya.

Melalui berbagi pendapat tersebut, dapat disimpulkan bahwa citraan merupakan kreativitas pengarang dalam menggambarkan suatu cerita dengan bahasa yang mampu menyentuh indra pembaca untuk dapat merasakannya.Citraan dapat dibagi menjadi beberapa jenis. Secara rinci Sutejo (2010: 20) membagi jenis citraan menjadi lima jenis sebagai yaitu (1) Citra penglihatan/visual imagery; (2) Citra pendengaran/audio imagery; (3) Citra penciuman; (4) Citra perabaan; dan (5) Citra gerak.

Karya sastra berkualitas bukan hanya terlihat dari bahasanya yang indah, namun juga kebermanfaatan karya sastra tersebut bagi para penikmatnya. Hal tersebut dapat dilihat dari nilai-nilai 
pendidikan karakter yang terkandung dalam karya sastra itu sendiri. Nilai pendidikan karakter terdiri dari dua konsep dasar, yaitu pendidikan dan karakter. Pendidikan merupakan sebuah proses belajar dan penyesuaian individu secara terus menerus terhadap nilai-nilai budaya, dan cita-cita masyarakat (Wibowo,2013: 2), sedangkankarakter merupakan nilainilai universal perilaku manusia yang meliputi seluruh aktivitas kehidupan, baik yang berhubungan dengan Tuhan, diri seniri, sesama manusia maupun dalam lingkungan yang terwujud dalam pikiran, sikap, perasaan, perkataan, dan perbuatan berdasarkan norma-norma agama, hukum, tata karma, budaya, serta adat istiadat (Suyadi, 2013:5).

Berdasarkan kedua konsep tersebut, muncullah istilah Pendidikan karakter yang merupakan upaya sadar dan terencana dalam mengetahui kebenaran atau kebaikan, mencintainya dan melakukannya dalam kehidupan sehari-hari (Suyadi, 2013:6).Kementerian Pendidikan Nasional (Kemendiknas) melalui buku Pengembangan Pendidikan Budaya dan Karakter Bangsa yang disusun oleh Badan Penelitian dan Pengembangan Pusat Kurikulum merumuskan 18 nilai pendidikan karakter yang akan ditanamkan dalam diri peserta didik sebagai upaya membangun karaker bangsa. Diantaranya nilai religius, jujur, toleransi, disiplin, kerja keras, kreatif, mandiri, demokratis, rasa ingin tahu, semangat kebangsaan (nasionalisme), cinta tanah air, menghargai prestasi, komunikatif, cinta damai, gemar membaca, peduli lingkungan, peduli sosial, dan tanggung jawab.

Kebermanfaatan karya sastra juga dapat masuk dalam proses pembelajaran di sekolah, hal tersebut dapat terjadi karena karya sastra relevan jika digunakan dan dikembangkan menjadi bahan ajar di sekolah, terutama pembelajaran Bahasa Indonesia. Bahan ajar sendiri merupakan segala bentuk bahan tertulis maupun tidak tertulis yang digunakan untuk membantu guru dalam melaksanakan proses pembelajaran di kelas (National Center for Vocational Education Research Ltd., dalam Prastowo 2014: 138). Pendapat mengenai bahan ajar juga disampaikan oleh Kodir (2011: 219) yang menyatakan bahwa bahan ajar adalah seperangkat materi yang disusun secara sistematis, baik tertulis maupun tidak tertulis sehingga tercipta lingkungan atau suasana yang memungkinkan siswa untuk belajar.

Bahan ajar sendiri memiliki peran yang pokok dalam pembelajaran (Prastowo, 2014:136), jadi penentuan penggunaan bahan ajar harus sesuai dengan karakteristik bahan ajar agar dapat mencapai tujuan dari pembelajaran. Berikut Paparan Suparman (2012: 284) mengenai ciri-ciri bahan ajar (1) Self Intructional; (2) Self Explanatory Power; (3) Self Paced Learning; (4) Self Contained; (5) Individualized Learning Materials; (6) Flexible and Mobile Learning Materials; (7) Communicative and Interactive Learning Materials; (8) Multimedia, Computer Based Materials; dan (9) Supported By Tutorials and Study Group. Yang dapat disederhanakan dengan lima karakteristik bahan ajar yang telah disampaikan oleh Widodo \& Jasmadi (dalam Lestari, 2013: 1), (1) Self Instructional, bahan ajar dapat membuat siswa membelajarkan diri sendiri dengan bahan ajar yang dikembangkan; (2) Self Contained, seluruh materi pelajaran dari satu unit kompetensi atau subkompetensi terdapat di dalam satu bahan ajar secara utuh; (3) Stand Alone, bahan ajar yang dikembangkan tidak tergantung pada bahan ajar lain; (4) Adaptive, memiliki daya adaptif yang tinggi terhadap perkembangan ilmu dan teknologi; dan (5) User Friendly, Setiap instruksi dan paparan informasi yang bersifat membantu dan bersahabat dengan pemakainya, termasuk kemudahan pemakaian dalam merespons dan mengakses semua dengan keinginan. 


\section{METODE PENELITIAN}

Penelitian ini menggunakan metode penelitian kualitatif dengan pendekatan analisis isi terhadap lirik-lirik lagu Fourtwnty album Lelaku.Jenis data penelitianini berupa data kualitatif, sumber data yang digunakan dalam penelitian ini berupa (1) Dokumen lirik-lirik lagu Fourtwnty album Lelakudengan unsur yang dikaji berupa unsur stilistika, nilainilai pendidikan karakter yang terdapat pada lirik lagu tersebut, dan relevansi liriklirik lagu tersebut sebagai bahan ajar pembelajaran Bahasa Indonesia pada tingkat SMA; (2) Silabus Bahasa Indonesia tingkat SMA; (3) Hasil wawancara yang berisi pendapat pengarang lirik lagu yang diteliti yaitu Ari Lesmana sebagai informan pertama dan guru Bahasa Indonesia SMK Negeri 1 Klaten Ninuk Siswantini, S.Pd sebagai informan kedua serta Suhirna, S.Pd sebagai informan ketiga.

Teknik pengumpulan sampel dalam penelitian ini berupa purposive sampling dengan objek penelitian yang diambil berupa sampel dalam lirik-lirik lagu Fourtwnty album Lelaku. Teknik pengumpulan data yang digunakan berupa wawancara secara mendalam terhadap pengarang lirik-irik lagu Fourtwnty album Lelakudan guru bahasa Indonesia, serta menggunakan teknik pengumpulan data berupa analisis dokumen lirik-lirik lagu Fourtwnty album Lelaku yang dikaitkan dengan kajian stilistika, nilai pendidikan karakter, dan relevansi sebagai bahan ajar pembelajaran Bahasa Indonesia. Peningkatan validitas dalam penelitian kualitatif ini menggunakan teknik triangulasi. Peneliti menggunakan triangulasimetode dan triangulasi teori.

Teknik analisis data yang digunakan berupa model analisis jalinan atau mengalir yang terdiri dari empat komponen, yaitu: (1) Pengumpulan Data, Peneliti mengumpulkan data yang bersumber dari lirik-lirik lagu Fourtwnty dalam album Lelaku; (2) Reduksi Data, berupa kegiatan menyeleksi data yang diperoleh kemudian mencatat informasi dari data tersebut dalam bentuk uraian secara rinci.; (3) Penyajian Data, data liriklirik lagu Fourtwnty dalam album Lelaku yang terkumpul dikelompokkan sesuai jenis permasalahan untuk kemudian dianalisis; (4) Penarikan Kesimpulan, pembuatan simpulan dari data-data yang diperoleh sejak awal penelitian. Setelah itu, disimpulkan bagaimana relevansinya sebagai bahan ajar pembelajaran Bahasa Indonesia di tingkat SMA.

\section{HASIL DAN PEMBAHASAN}

Lirik-lirik pada lagu Fourtwnty album Lelaku dikaji menggunakan analisis stilistika dan adanya nilai-nilai pendidikan karakter serta relevansinya sebagai bahan ajar pembelajaran Bahasa Indonesia kelas $X$ di tingkat SMA. Lirik-lirik lagu Fourtwnty album Lelakumenarik untuk diteliti karena bahasa yang terdapat dalam lirik-lirik lagu tersebut memiliki kekhasan yang tidak hanya indah namun juga mengandung adanya pesan-pesan moral, hal tersebut didukung oleh Ninuk Siswantini, S.Pd sebagai guru Bahasa Indonesia di SMK Negeri 1 Klaten yang menyatakan bahwa lirik-lirik lagu Fourtwnty layak dikaji menggunakan analisis stilistika karena mengandung adanya gaya bahasa, diksi, pencitraan, dan nilai-nilai pendidikan yang dapat mencerminkan bahwa lirik-lirik lagu tersebut berkualitas dan dapat dijadikan bahan penelitian lebih lanjut lagi. Ari Lesmana sebagai pengarang lirik-lirik lagu Fourtwnty menyampaikan bahwa lirik-lirik lagu yang dibuatnya merupakan hasil dari pandangannya terhadap hal-hal yang terjadi di kehidupan sehari-hari.

\section{Gaya Bahasa pada Lirik-Lirik Lagu Fourtwnty dalam Album Lelaku Gaya bahasa merupakan pengungkapan bahasa seorang pengarang yang memiliki peranan untuk memunculkan aspek keindahan dalam karya sastra. Ari Lesmana sebagai pengarang lirik-lirik lagu Fourtwnty dalam}


album Lelaku telah menggunakan gaya bahasa yang khas dalam penciptaan liriklirik lagunya untuk dapat menunjang aspek keindahan, diantaranya telah menggunakan 8 gaya bahasa 22 sinpoke, 14 repetisi epizeuksis, 13 simbolik, 8 gaya bahasa afersis, 7 pararelisme, 7 alegori, 4 repetisi anafora, 4 simile, 4 repetisi mesodiplosis, 5 antitesis, 3 repetisi aliterasi, 2 arkhaisme, 2 paterio, 2 retoris, 2 litotes, 2 kontradiksio, 1 repetisi asonasi, 1 repetisi epanalepsis, 1 repetisi epifora, 1 repetisi kiasmus, 1 aforisme, 1 hiperbola, 1 anakronisme, dan 1 sakrasme.

Gaya bahasa dominan yang digunakan Ari Lesmana dalam penulisan lirik-lirik lagu Fourtwnty album Lelaku yaitu gaya bahasa sinpoke yang berfungsi menciptakan efek keindahan dengan sengaja menghilangkan suatu suku kata di tengah kata, repetisi epizeuksis yang berfungsi memberi keindahan dan tekanan pada suku kata atau bagian dari kalimat yang dianggap penting dengan melakukan perulangan kata atau kalimat secara langsung serta simbolik yang berfungsi memberi efek keindahan serta kekhasan dengan menyampaikan makna melalui sebuah simbol.Secara keseluruhan gaya bahasa yang digunakan Ari Lesmana mampu menimbulkan efek indah, kekhasan, dan efek penegasan pada liriklirik lagu Fourtwnty album Lelaku

Pilihan Kata atau Diksi pada LirikLirik Lagu Fourtwnty dalam Album Lelaku

Ari Lesmana telah menggunakan beberapa diksi dalam penulisan karyanya yang berupa lirik-lirik lagu yaitu 115 kata sapaan khas dan nama diri, 20 kata konotatif, 8 kata dengan objek realitas alam, 5 kata konkret, serta 1 kata vulgar. Pilihan kata yang dominan dalam lirik-lirik lagu Fourtwnty album Lelaku yaitu kata konotatif yang merupakan pengungkapan perasaan dan pikiran pengarang yang bersifat komunikatif serta terlepas dari makna harafiahnya dan kata sapaan khas dan nama diri yang merupakan jenis pilihan kata yang digunakan untuk menyebut serta merujuk seseorang atau identitas seseorang.Pemilihan kata yang digunakan Ari Lesmana pada lirik-lirik lagu Fourtwnty dalam album Lelaku dapat menciptakan keindahan dan kekhasan pada karya sastra itu sendiri.

\section{Citraan pada Lirik-Lirik Lagu Fourtwnty dalam Album Lelaku}

Lirik-lirik lagu Fourtwnty album Lelaku mengandung 15 citra penglihatan, 8 citra pendengaran, dan 4 citra gerak. Citraan yang paling menonjol dalam liriklirik lagu Fourtwnty album Lelaku yaitu citra penglihatan yang mampu merangsang indra penglihatan pembaca atau pendengar untuk seolah-olah dapat melihat secara langsung sesuatu yang digambarkan menggunakan bahasa. Citraan yang terdapat dalam lirik-lirik lagu Fourtwnty album Lelaku mampu membangkitkan imaji pembaca untuk dapat seolah-olah merasakan secara langsung kejadian yang digambarkan penulis dengan bahasa yang indah.

\section{Nilai Pendidikan Karakter pada Lirik- Lirik Lagu Fourtwnty dalam Album Lelaku}

Karya sastra sebagai ungkapan perasaan pengarang melalui bahasa bukan hanya memiliki fungsi keindahan namun juga kebergunaan bagi pengarang sendiri maupun bagi para penikmatnya. Melalui wawancara, Ari Lesmana sebagai pengarang lirik-lirik lagu Fourtwnty album Lelaku menyampaikan keyakinannya bahwa lirik lagu yang telah ia ciptakan mampu mengubah karakter pendengarnya untuk menjadi lebih baik. Ninuk Siswantini, S.Pd melalui wawancara juga memiliki keyakinan bahwa lirik-lirik lagu Fourtwnty dalam album Lelaku dapat membentuk semangat siswa untuk menjadi pribadi yang berpendidikan dan berbudi pekerti luhur.

Lirik-lirik lagu Fourtwnty dalam album Lelaku terdapat nilai pendidikan karakter berupa 6 nilai komunikatif, 6 nilai 
cinta damai, 4 nilai peduli sosial, 3 nilai religius, 3 nilai kerja keras, 2 nilai toleransi,2 nilai peduli lingkungan, 1 nilai kejujuran atau jujur, 1 nilai demokratis, dan 1 nilai rasa ingin tahu. Nilai pendidikan karakter yang menonjol yaitu nilai religius, kerja keras, komunikatif, dan cinta damai.

Religius merupakan kecintaan dan ketaatan terhadap Tuhan serta agama yang dianut dan sikap toleran terhadap keberlangsungan ibadah agama lain. Adanya nilai-nilai religius dalam karya sastra diharapkan mampu menciptakan rasa cinta kasih terhadap Tuhan dan sesama.

Kerja keras merupakan usaha seseorang dalam mengerjakan pekerjaan atau tanggunga jawab secara maksimal dan total hingga tercapainya tujuan serta hasil yang maksimal. Ari Lesmana sebagai pengarang lagu Fourtwnty dalam wawancara mengakui bahwa lirik-lirik lagu yang ia buat telah memengaruhi atau memotivasi beberapa pecinta karyanya dalam membangun usaha.

Komunikatif merupakan sikap yang bersahabat atau dapat membuka diri terhadap orang lain melalui ucapan dan tindakan yang santun sehingga dapat menciptakan hubungan yang baik. Diharapkan pembaca atau pendengar mampu menjalin relasi yang baik dengan sesama melalui komunikasi berupa ucapan dan tindakan yang tepat. Cinta damai merupakan sikap dan tindakan yang selalu berusaha menciptakan suasana damai, nyaman, tenang, aman, dan adanya suasana saling mengasihi satu sama lain. Diharapkan pembaca atau pendengar dapat terinspirasi untuk selalu menciptakan suasana damai pada lingkungan dan sesama.

Lirik-Lirik Lagu Fourtwnty Album Lelaku sebagai Bahan Ajar Bahasa Indonesia di Kelas X SMA

Berdasarkan kesesuaian lirik-lirik lagu Fourtwnty album Lelaku dengan silabus pembelajaran Bahasa Indonesia kelas $\mathrm{X}$ tingkat SMA/MA/SMK/MAK dalam kompetensi dasar 3.8 menganalisis puisi bertema sosial, budaya, dan kemanusiaan dengan memperhatikan struktur fisik (tipografi, diksi, imaji, kata konkret, bahasa figuratif, verifikasi: rima, ritme, dan metrum) dan struktur batin puisi (tema, feeling, nada, dan amanat) serta 4.8 menulis puisi bertema sosial, budaya, dan kemanusiaan dengan memperhatikan struktur fisik (tipografi, diksi, imaji, kata konkret, bahasa figuratif, verifikasi: rima, ritme, dan metrum) dan struktur batin puisi (tema, feeling, nada, dan amanat).

Berdasarkan hasil wawancara terhadap Ninuk Siswantini, S.Pd dan Suhirna, S.Pd sebagai guru Bahasa Indonesia di SMK Negeri 1 Klaten yang menyatakan bahwa lirik-lirik lagu Fourtwnty dalam album Lelakudapat dijadikan sebagai bahan pembelajaran Bahasa Indonesia pada materi Apresiasi Puisi tingkat SMA/MA/SMK/MAK, karena lirik lagu Fourtwnty dalam album Lelaku mengandung unsur-unsur intrinsik yang berisi tema, amanat, gaya bahasa, diksi, dan yang lainnya. Selain itu, juga karena terdapat kesesuaian lirik-lirik lagu Fourtwnty dengan karakteristik bahan ajar yang berupa Self Instructional Self Contained Stand, dan Alone Adaptive. Penjelasaannya bisa diuaraikan berikut ini.

Self Instructional, lirik-lirik lagu Fourtwnty yang dikembangkan sebagai bahan ajar pembelajaran, siswa dapat belajar secara mandiri karena lirik lagu tersebut adalah salah satu media hiburan yang mudah untuk di dapatkan dan menarik untuk dinikmati siswa, sehingga dapat menarik minat siswa untuk menjadikannya sebagai bahan belajar.

Self Contained, lirik-lirik lagu Fourtwnty album Lelaku mengandung adanya struktur fisik dan batin puisi relevan dengan KD 3.8 dan 4.8 yang membahas mengenai struktur fisik dan batin puisi.

Stand Alone, lirik-lirik lagu Fourtwnty dalam album Lelaku dapat digunakan 
seutuhnya dan tidak bergantung pada bahan ajar lain, karena pada lirik-lirik lagu Fourtwnty album Lelaku sendiri telah mengandung adanya struktur fisik dan struktur batin puisi yang dapat digunakan sebagai bahan pembelajaran Apresiasi Puisi.

Adaptive, lirik-lirik lagu Fourtwnty dalam album Lelaku bila dikembangkan menjadi bahan ajar dapat disajikan bukan hanya melalui teks, namun juga dapat melalui audio. Hal ini dapat membuktikan bahwa lirik-lirik lagu Fourtwnty album Lelaku memiliki daya adaptif terhadap perkembangan ilmu berupa perkembangan pengetahuan mengenai puisi yang penyajiannya tidak hanya terbatas pada teks dan daya adaptif terhadap perkembangan teknologi berupa pemanfaatan teknologi audio.

User Friendly, lirik-lirik lagu Fourtwnty album Lelaku bila dikembangan menjadi bahan ajar akan mudah diterima oleh siswa karena menggunakan gaya bahasa dan diksi yang sesuai serta dekat dengan remaja usia tingkat SMA. Lirik-lirik lagu Fourtwnty album Lelaku juga mudah didapat melalui internet.

Lirik-lirik lagu Fourtwnty album Lelaku dapat digunakan dan dikembangkan sebagai bahan ajar Bahasa Indonesia pembelajaran Apresiasi Puisi kelas $\mathrm{X}$ di tingkat SMA.

\section{SIMPULAN}

Berdasarkan hasil analisis terhadap lirik-lirik lagu Fourtwnty album Lelaku

\section{REFERENSI}

Al-Ma'ruf, A. (2009). Stilistika: Teori, Metode, dan Aplikasi Pengkajian Estetika Bahasa. Solo: CakraBooks.

Erowati, Mualim. (2015). Perbandingan Gaya Bahasa pada Puisi 'Ibu' Karya Mustofa Bisti dengan Lirik Lagu 'Keramat' Karya Rhoma Irama. Dialektika, 2 (2), 171-193. dapat ditarik kesimpulan bahwa Gaya bahasa yang terdapat pada lirik-lirik lagu Fourtwnty dalam album Lelaku karya Ari Lesmana didominasi oleh gaya bahasa sinpoke (22), repetisi epizeuksis (14), dan simbolik (13) yang mampu menciptakan efek estetis, khas, serta penegasan. Pilihan kata atau diksi yang terdapat pada liriklirik lagu Fourtwnty dalam album Lelaku didominasi oleh kata sapaan khas serta nama diri (115) dan konotatif (20). Pemilihan kata dominan yang digunakan Ari Lesmana pada lirik-lirik lagu Fourtwnty dalam album Lelaku dapat menciptakan keindahan dan kekhasan pada lirik lagu.

Citraan yang terdapat pada lirik-lirik lagu Fourtwnty dalam album Lelaku didominasioleh citra penglihatan (15) yang mampu merangsang indra penglihatan pembaca atau pendengar untuk seolah-olah dapat melihat secara langsung sesuatu yang digambarkan melalui bahasa.Nilai pendidikan karakter yang menonjol dalam lirik-lirik lagu Fourtwnty album Lelaku yaitu nilaikomunikatif (6), cinta damai (6), religius (3), dan kerja keras (3)yangdiciptakan untuk dapat membentuk karakter pembaca atau pendengar menjadi pribadi lebih baih.Lirik-lirik lagu Fourtwnty album Lelaku dapat digunakan dan dikembangkan sebagai bahan ajar pembelajaran Bahasa Indonesia kelas X khususnya pada pelajaran apresiasi puisi pada kompetensi dasar 3.8 dan 4.8. Liriklirik lagu Fourtwnty album Lelaku telah memenuhi karakteristik bahan ajar berupa Self Instructional, Self Contained, Stand Alone, Adaptive, dan User Friendly.

Hartono. (2003). Stilistika Genetik Studi Kasus Penggunaan Gaya Bahasa dalam Cerpen Godlob Karya Danarto. Humaniora. 8 (2), 1-21.

Keraf, G. (2007). Diksi dan Gaya Bahasa. Jakarta: Gramedia.

Kodir, A. (2011). Strategi Belajar Mengajar. Bandung: Pustaka Setia. 
Lestari, I. (2013). Pengembangan Bahan Ajar Berbasis Kompetensi: sesuai dengan Kurikulum Tingkat satuan Pendidikan. Padang: Akademia Permata.

Prastowo, A. (2014). Pengembangan Bahan Ajar Tematik. Jakarta: Kencana.

Ratna, N. K. (2013). Stilistika, Kajian Puitika Bahasa, Sastra, dan Budaya. Yogyakarta: Pustaka Pelajar.

Rokhmansyah, A. (2014). Studi dan Pengkajian Sastra, Pendekatan Awal Terhadap Ilmu Sastra. Yogyakarta: Graha Ilmu.

Suparman, M. A. (2012). Desain Intruksional Moderen. Jakarta: Erlangga.

Satoto, S. (2012). Stilistika. Yogyakarta: Penerbit Ombak.

Sutardi, H. K. (2012). Penelitian Sastra Kreatif. Yogyakarta: Graha Ilmu.

Sutejo. (2010). Stilistika. Yogyakarta: Pustaka Felicha.

Suyadi. (2013). Strategi Pembelajaran Pendidikan Karakter. Bandung: PT Remaja Rosdakarya.

Wibowo, A. (2013). Pendidikan Karakter Berbasis Sastra: Internalisasi NilaiNilai Karakter Melalui Pengajaran Sastra. Yogyakarta: Pustaka Pelajar. 